\title{
Effect of Micro Catchment Techniques on Vegetative Growth of Jatropha (Jatropha Curcas)
}

\author{
Azmi Elhag Aydrous ${ }^{1}$, Abdel Moneim Elamin Mohamed², Abdelbagi Ahmed Abdelbagi ${ }^{3}$ \\ ${ }^{1}$ Department of Agricultural Engineering, Faculty of Agriculture, Omdurman Islamic University, Omdurman, Sudan \\ ${ }^{2}$ Department of Agricultural Engineering, Faculty of Agriculture, University of Khartoum, Khartoum, Sudan \\ ${ }^{3}$ Department of Crops sciences, Faculty of Agriculture, Omdurman Islamic University, Omdurman, Sudan
}

Email address:

azmielhag@yahoo.com (A. E. Aydrous)

\section{To cite this article:}

Azmi Elhag Aydrous, Abdel Moneim Elamin Mohamed, Abdelbagi Ahmed Abdelbagi. Effect of Micro Catchment Techniques on Vegetative Growth of Jatropha (Jatropha Curcas). American Journal of Agriculture and Forestry. Vol. 3, No. 2, 2015, pp. 52-57.

doi: 10.11648/j.ajaf.20150302.17

\begin{abstract}
This study was conducted during two consecutive seasons (2011/2012 and 2012/2013) at the southern Omdurman region near Khartoum New International Airport (KNIA) to evaluate the effect of four rain water harvesting micro catchment techniques on some growth attributes of Jatropha trees. The micro catchments used were semicircular, pits, deep ditch and Vshape in addition to the control. A randomized complete block design with four replications was used to study the effect of these techniques on trees growth. The results of the study showed that plant height, stem thickness (for some cases) and number of leaves/tree for Jatropha trees were significantly increased under the micro catchment techniques as compared to the control, with higher mean obtained by V-shape.
\end{abstract}

Keywords: Micro-Catchment Techniques, Jatropha

\section{Introduction}

Water erosion is dominant in semi arid zones. Sudan is suffering from water erosion and water eroded soils in Sudan was estimated to be about 8 million hectares (Akhtar and Menching, 1993). Water harvesting techniques were used in Sudan for increasing agricultural production Omer et al (1997). For trees also Salih and Iinanga (1997) tried this for increasing production of sorghum and gum. The main reducing effect of vegetation on flooding and runoff water erosion is that vegetation roots act as a binding agent to soil particles. In addition, litter and roots which decay in the soil act as a cementing agent that improves soil structure and that vegetation canopy intercepts rain drops and reduces soil erosion caused by rain drop splash (Alaktar and Aga, 1995). Vegetation also reduces runoff speed and thus reduces its capacity to detach and remove soil particles. The alterations it makes to soil through combination of actions such as root binding effect, leaf and litter humus formation, the cover delay and reduce volume of flood and intercept rain drops (Alaktar and Aga, 1995). Forest cover may probably cut at least the peak flow by $80 \%$ and run off volume by $40 \%$, besides removal of shrubs and grasses cause potential erosion risk (Meunive, 1996). Young (1989) reported that $60-75 \%$ of ground cover maintained through the rainy season was effective against erosion of vertisols in Australia. Also Meunive (1996) indicated that with $40 \%$ cover grown mainly in gully reduced sediment yield as much as $92.5 \%$ even during storms. Mechanical means for erosion control can be used such as cut -off drain technique or other methods can be used to reduce erosion. But it should be complemented by plant cover for everlasting and sustainable protection. Plant cover protects soil from direct rain drops and roots of plants bind soil particles and falling litter latter improves physical and chemical soil properties. The objectives of this study were to investigate the effect of the water harvesting techniques on the growth of Jatropha.

\section{Materials and Methods}

The experimental work was conducted at Jebel Awlia locality 40 kilometers south of Omdurman city and 25 kilometers from the west bank of the White Nile River during 2010-2011 and 2011-2012 rainy seasons. The experiments covered an area of 5 hectares as a part of the area designated for Khartoum New International Airport. The climate of the area is semi desert, which was characterized by high 
temperature of an average of $45^{\circ} \mathrm{C}$ during the summer. Wind speed is very high evoking dust. Very sparse herbaceous plants and Acacia trees comprise the plant cover which is green during the rainy season. The soil is light to sandy in composition except at lane beds especially Mansourab dam. Soil changes gradually to clay and sand-clay according to level and topography.

Five water harvesting techniques were used as follows:

1. Cultivation on land without water harvesting technique (control) treatment denoted by $\left(\mathrm{T}_{0}\right)$.

2. Cultivation with semi- circular water traps, designed with 30 meters diameter and $90 \mathrm{~cm}$ height. The distance between one trap and another is 20 meters Jatropha (Jatropha curcas) seedlings were sown at the inside the bank of the semi-circular trap with spacing of 4 meters between plants. The water dikes were composed of 3 units, and the dikes were 50 meters from the next unit of dikes $\left(\mathrm{T}_{1}\right)$.

3. V-shaped water dikes: Each side was 30 meters long and at the bottom of the $\mathrm{V}$-shape dikes the distance is also 30 meters. The distance between a set of dikes and the other was 20 meters. The water trap was composed of 3 shapes at the front and 2shapes at the rear at a distance of 50 meters between the front and rear. The previously mentioned tree species were also sown intent of the dikes at a distance of 4 meters between plants $\left(\mathrm{T}_{4}\right)$.

4. Pits: The pits were designed at 5 meters width, 10 meters length and 10 meters between pits. Pits were dug according to the land gradient. Water trap was composed of 3 pits at the front and 2 pits at the rear at a distance of 50 meters between the front and rear pits. The previously mentioned tree species were sown with the same spacing at 4 meters between plants $\left(\mathrm{T}_{2}\right)$.

5. Deep ditches: The deep ditches were dug by a motor grader. The length of each ditch was 30 meters and depth of $90 \mathrm{~cm}$, at a distance of 20 meters between ditches. The water trap in this design was composed of 3 ditches at the front and 2 ditches at the rear. The distance between the front and rear ditches was 50 meters, the trees seedlings were sown at the inside of each ditch at spacing of 4 meters between plants, $\left(\mathrm{T}_{3}\right)$.

\section{Seedlings:}

The seedlings were raised in the Air Port nursery and were transplanted when they were six months old at the onset of the rainy season to give the seedlings the full benefit of the rainy season.

Plant parameters:

The following parameters were taken every month starting after planting.

a) Plant height $(\mathrm{cm})$ :

Five plants were chosen at random from each treatment. Plant height was taken from the base of the plant to the top by using a metering device. The mean height of the five plants was recorded.

b) Number of leaves per plant:

Five plants were taken at random from each treatment so as to count the number of leaves per plant, and the mean number of the leaves of the five plants was recorded.

c) Number of branches per plant:

Five plants were taken at random from each treatment so as to count the number of branches per plant, and the mean number of the branches of the five plants was recorded.

d) Stem thickness:

Five plants were chosen at random from each treatment. Stem diameter was measured using a vernia. The mean stem diameter of the five plants was recorded.

\section{Results}

\subsection{Plant Height (cm)}

Table 1 (before mortality of control trees) show that Vshape treatment during November and December in both seasons and during January in the first season showed a significantly higher mean of plant height as compared to all other treatments, except with pits during November in both seasons. On the other hand, this treatment during October had a significantly higher mean of plant height only as compared to pits in the first season and the control in the second season, whereas it had no significant differences with all other treatments (Table 1). Meanwhile, both semi-circular and deep ditch treatments in December and January of the first season and during October, November and December of the second season gave a significantly higher mean of plant height than the control treatment, except deep ditch during December of the first season, when there were no significant differences between them (Table 1).

Table 1. Effect of micro catchment shape on plant height (cm) of Jatropha (before mortality of control trees) during 2011/2012 and 2012/2013 seasons.

\begin{tabular}{|c|c|c|c|c|c|c|c|}
\hline \multirow{2}{*}{ Treatments } & \multicolumn{4}{|c|}{ Plant height (cm) First season } & \multicolumn{3}{|c|}{ Plant height $(\mathrm{cm})$ Second season } \\
\hline & October & November & December & January & October & November & December \\
\hline T0 & $28.07^{\mathrm{ab}}$ & $28.77^{b}$ & $28.78^{d}$ & $29.47^{\mathrm{c}}$ & $27.72^{b}$ & $28.05^{\mathrm{d}}$ & $28.16^{\mathrm{e}}$ \\
\hline T1 & $25.33^{b}$ & $28.73^{b}$ & $34.50^{b c}$ & $40.47^{\mathrm{b}}$ & $29.37^{\mathrm{ab}}$ & $32.65^{b}$ & $36.07^{\mathrm{c}}$ \\
\hline $\mathrm{T} 2$ & $28.23^{\mathrm{ab}}$ & $31.93^{\mathrm{ab}}$ & $36.90^{\mathrm{b}}$ & $42.33^{b}$ & $31.24^{\mathrm{a}}$ & $34.99^{\mathrm{a}}$ & $39 . .95^{b}$ \\
\hline T3 & $26.07^{\mathrm{b}}$ & $29.33^{b}$ & $32.63^{\mathrm{cd}}$ & $39.50^{b}$ & $29.63^{\mathrm{a}}$ & $31.34^{\mathrm{c}}$ & $33.80^{d}$ \\
\hline $\mathrm{T} 4$ & $29.57^{\mathrm{a}}$ & $33.60^{\mathrm{a}}$ & $41.50^{\mathrm{a}}$ & $49.60^{\mathrm{a}}$ & $29.79^{\mathrm{a}}$ & $34.78^{a}$ & $47.04^{\mathrm{a}}$ \\
\hline $\mathrm{SE} \pm$ & 0.98 & 1.13 & 1.20 & 1.23 & 0.58 & 0.59 & 0.57 \\
\hline
\end{tabular}

Means with the same latter(s) in the same column are not significantly different at 0.05 level of probability according to Duncan's New Multiple Range Test (DNMRT).

$\mathrm{T}_{0}=$ control; $\mathrm{T}_{1}=$ semi-circular; $\mathrm{T}_{2}=$ pits; $\mathrm{T}_{3}=$ deep ditch; $\mathrm{T}_{4}=\mathrm{V}$-shape.

Table 2 (after mortality of control trees) shows that Vshape treatment during February, March and April in both seasons and during January in the second season reported a significantly higher mean of plant height as compared to all 
other treatments (semi-circular, pits and deep ditch). Also the Table shows that both semi-circular and pits treatments in this period showed no significant differences between them, except during March and April in the second season, but both of them had a significantly higher mean of plant height as compared to deep ditch during the same period, except with pits during February and March in the first season and during April of the second season.

\subsection{Stem Thickness (cm)}

In the first season the V-shaped treatment during November, December and January had significantly higher mean of stem diameter as compared to all other treatments, except with the control and pits during November and semicircular during December (Table 3). Meanwhile the V-shaped treatment during December in the second season significantly increased stem diameter as compared to both control and deep ditch treatments. On the other hand, both control and pits during November in the first season had significantly higher mean of stem diameter as compared to semi-circular, but during December and January of the same season the reverse was true (Table 3). During December of the second season there were no significant differences between these treatments (Table 3). Meanwhile deep ditch treatment in both seasons for most months reported a significantly lower mean of stem thickness than all the other treatments (Table 3 ).

Table 4 (after mortality of control trees) reveals that the Vshaped treatment in both seasons for all months had a significantly higher mean of stem thickness as compared to the semi-circular, pits and deep ditch treatments, except with the semi-circular during January and April in the second season. In the first season for all months, the semi-circular reported a significantly higher mean of stem thickness as compared to both pits and deep ditch (Table 4). Whereas in the second season this treatment significantly increased stem diameter as compared to deep ditch during January, February and April, while the reverse was true during March. As for pits and deep ditch treatments (Table 4) shows that there were no significant differences between these treatments in both seasons.

Table 2. Effect of micro catchment shape on plant height (cm) of Jatropha (after mortality of control trees) during 2011/2012 and 2012/2013 seasons.

\begin{tabular}{|c|c|c|c|c|c|c|c|}
\hline \multirow{2}{*}{ Treatments } & \multicolumn{3}{|c|}{ Plant height (cm) First season } & \multicolumn{4}{|c|}{ Plant height $(\mathrm{cm})$ Second season } \\
\hline & February & March & April & January & February & March & April \\
\hline T1 & $46.80^{b}$ & $51.93^{b}$ & $53.77^{b}$ & $43.06^{b}$ & $46.66^{b}$ & $53.51^{b}$ & $55.59^{b}$ \\
\hline $\mathrm{T} 2$ & $48.37^{\mathrm{b}}$ & $52.23^{\mathrm{b}}$ & $53.17^{\mathrm{bc}}$ & $44.61^{\mathrm{b}}$ & $46.85^{b}$ & $48.82^{\mathrm{c}}$ & $50.17^{c}$ \\
\hline $\mathrm{T} 3$ & $45.30^{b}$ & $47.70^{b}$ & $48.47^{\mathrm{c}}$ & $36.23^{c}$ & $39.83^{c}$ & $41.01^{\mathrm{d}}$ & $41.86^{\mathrm{d}}$ \\
\hline $\mathrm{T} 4$ & $58.00^{\mathrm{a}}$ & $64.37^{\mathrm{a}}$ & $66.10^{\mathrm{a}}$ & $50.14^{\mathrm{a}}$ & $54.28^{\mathrm{a}}$ & $56.53^{\mathrm{a}}$ & $58.79^{\mathrm{a}}$ \\
\hline $\mathrm{SE} \pm$ & 1.28 & 1.48 & 1.47 & 0.61 & 0.61 & 0.64 & 0.63 \\
\hline
\end{tabular}

Means with the same latter(s) in the same column are not significantly different at 0.05 level of probability according to DNMRT.

$\mathrm{T}_{1}=$ semi-circular; $\mathrm{T}_{2}=$ pits; $\mathrm{T}_{3}=$ deep ditch; $\mathrm{T}_{4}=\mathrm{V}$-shape.

Table 3. Effect of micro catchment shape on stem thickness (cm) of Jatropha (before mortality of control trees) during 2011/2012 and 2012/2013 seasons.

\begin{tabular}{|c|c|c|c|c|c|c|c|}
\hline \multirow{2}{*}{ Treatments } & \multicolumn{3}{|c|}{ Stem thickness (cm) First season } & \multicolumn{4}{|c|}{ Stem thickness $(\mathrm{cm})$ Second season } \\
\hline & October & November & December & January & October & November & December \\
\hline T0 & $5.23^{\mathrm{ab}}$ & $5.74^{\mathrm{a}}$ & $5.79^{\mathrm{b}}$ & $5.97^{\mathrm{d}}$ & $4.72^{\mathrm{a}}$ & $4.78^{\mathrm{a}}$ & $4.85^{b}$ \\
\hline T1 & $4.98^{\mathrm{ab}}$ & $5.33^{\mathrm{bc}}$ & $6.57^{\mathrm{a}}$ & $6.93^{\mathrm{b}}$ & $5.07^{\mathrm{a}}$ & $5.38^{\mathrm{a}}$ & $5.94^{\text {a }}$ \\
\hline $\mathrm{T} 2$ & $5.01^{\mathrm{ab}}$ & $5.47^{\mathrm{a}}$ & $5.98^{b}$ & $6.23^{c}$ & $4.82^{\mathrm{a}}$ & $5.07^{\mathrm{a}}$ & $5.47^{\mathrm{ab}}$ \\
\hline $\mathrm{T} 3$ & $4.74^{b}$ & $4.98^{c}$ & $5.21^{\mathrm{c}}$ & $5.89^{\mathrm{cd}}$ & $4.62^{\mathrm{a}}$ & $4.86^{\mathrm{a}}$ & $5.10^{\mathrm{b}}$ \\
\hline $\mathrm{T} 4$ & $5.27^{\mathrm{a}}$ & $5.71^{\text {a }}$ & $6.98^{\mathrm{a}}$ & $7.43^{\mathrm{a}}$ & $4.97^{\mathrm{a}}$ & $5.31^{\mathrm{a}}$ & $6.10^{\mathrm{a}}$ \\
\hline $\mathrm{SE} \pm$ & 0.16 & 0.12 & 0.13 & 0.13 & 0.17 & 0.21 & 0.23 \\
\hline
\end{tabular}

Means with the same latter(s) in the same column are not significantly different at 0.05 level of probability according to DNMRT.

$\mathrm{T}_{0}=$ control; $\mathrm{T}_{1}=$ semi-circular; $\mathrm{T}_{2}=$ pits; $\mathrm{T}_{3}=$ deep ditch; $\mathrm{T}_{4}=\mathrm{V}$-shape.

Table 4. Effect of micro catchment shape on stem thickness (cm) of Jatropha (after mortality of control trees) during 2011/2012 and 2012/2013 seasons.

\begin{tabular}{|c|c|c|c|c|c|c|c|}
\hline \multirow{2}{*}{ Treatments } & \multicolumn{3}{|c|}{ Stem thickness (cm) First season } & \multicolumn{4}{|c|}{ Stem thickness (cm) Second season } \\
\hline & February & March & April & January & February & March & April \\
\hline $\mathrm{T} 1$ & $7.09^{b}$ & $7.18^{\mathrm{b}}$ & $7.29^{b}$ & $6.41^{\mathrm{ab}}$ & $6.91^{\mathrm{b}}$ & $7.40^{\mathrm{c}}$ & $7.81^{\mathrm{ab}}$ \\
\hline $\mathrm{T} 2$ & $6.47^{\mathrm{c}}$ & $6.51^{\mathrm{c}}$ & $6.57^{\mathrm{c}}$ & $5.69^{\mathrm{bc}}$ & $5.81^{\mathrm{c}}$ & $5.98^{b}$ & $6.39^{\mathrm{bc}}$ \\
\hline $\mathrm{T} 3$ & $6.23^{c}$ & $6.31^{\mathrm{c}}$ & $6.33^{c}$ & $5.44^{\mathrm{c}}$ & $5.67^{\mathrm{c}}$ & $5.84^{b}$ & $5.99^{\mathrm{c}}$ \\
\hline $\mathrm{T} 4$ & $7.93^{\mathrm{a}}$ & $8.21^{\mathrm{a}}$ & $8.87^{\mathrm{a}}$ & $6.64^{\mathrm{a}}$ & $7.31^{\mathrm{a}}$ & $8.02^{\mathrm{a}}$ & $8.57^{\mathrm{a}}$ \\
\hline $\mathrm{SE} \pm$ & 0.12 & 0.13 & 0.12 & 0.25 & 0.25 & 0.29 & 0.25 \\
\hline
\end{tabular}

Means with the same latter(s) in the same column are not significantly different at 0.05 level of probability according to DNMRT.

$\mathrm{T}_{1}=$ semi-circular; $\mathrm{T}_{2}=$ pits; $\mathrm{T}_{3}=$ deep ditch; $\mathrm{T}_{4}=\mathrm{V}$-shape.

\subsection{Number of Leaves/Tree}

Table 5 (before mortality of control trees) shows that in the first season the V-shaped treatment for all months had a significantly higher mean number of leaves/tree as compared to all other treatments. While, during December in the second season this treatment significantly increased the number of leaves/tree as compared to the control and deep ditch treatment. On the other hand, pits gave a significantly higher 
mean number of leaves/tree as compared to the control and semi-circular treatments in both seasons for all months, except during December in the second season, when there was no significant difference between it and semi-circular treatment (Table 5). Similarly deep ditch treatment significantly increased number of leaves/tree as compared to control in both seasons for all the months (Table 5).

Table 6 (after mortality of control trees) also shows that the V-shaped treatment significantly increased the number of leaves/tree as compared to all other treatments in both seasons for all months, except with pits during February and March of the first season and January of the second season and with the semi-circular during January and February of the second season.

On the other hand, there were no significant differences between the semi-circular, pits and the deep ditch for the number of leaves/tree in the first season, except during

Table 5. Effect of micro catchment shape on number of leaves/tree of Jatropha (before mortality of control trees) during 2011/2012 and 2012/2013 seasons.

\begin{tabular}{|c|c|c|c|c|c|c|c|}
\hline \multirow{2}{*}{ Treatments } & \multicolumn{4}{|c|}{ Number of leaves/tree First season } & \multicolumn{3}{|c|}{ Number of leaves/tree Second season } \\
\hline & October & November & December & January & October & November & December \\
\hline T0 & $3.33^{\mathrm{c}}$ & $5.00^{\mathrm{c}}$ & $8.00^{\mathrm{d}}$ & $0.67^{\mathrm{d}}$ & $5.67^{\mathrm{a}}$ & $7.33^{\mathrm{a}}$ & $3.33^{\mathrm{c}}$ \\
\hline $\mathrm{T} 2$ & $9.67^{\mathrm{b}}$ & $12.00^{\mathrm{b}}$ & $15.33^{b}$ & $23.00^{\mathrm{b}}$ & $7.00^{\mathrm{a}}$ & $10.67^{\mathrm{a}}$ & $16.00^{\mathrm{a}}$ \\
\hline T3 & $8.00^{\mathrm{b}}$ & $10.66^{\mathrm{b}}$ & $14.00^{\mathrm{bc}}$ & $19.33^{\mathrm{c}}$ & $5.33^{\mathrm{a}}$ & $9.33^{\mathrm{a}}$ & $10.00^{b}$ \\
\hline $\mathrm{T} 4$ & $15.33^{\mathrm{a}}$ & $19.00^{\mathrm{a}}$ & $24.00^{\mathrm{a}}$ & $26.33^{\mathrm{a}}$ & $7.33^{\mathrm{a}}$ & $10.33^{\mathrm{a}}$ & $14.67^{\mathrm{a}}$ \\
\hline
\end{tabular}

Means with the same latter(s) in the same column are not significantly different at 0.05 level of probability according to DNMRT.

$\mathrm{T}_{0}=$ control; $\mathrm{T}_{1}=$ semi-circular; $\mathrm{T}_{2}=$ pits; $\mathrm{T}_{3}=$ deep ditch; $\mathrm{T}_{4}=\mathrm{V}$-shape.

Table 6. Effect of micro catchment shape on number of leaves/tree of Jatropha (after mortality of control trees) during 2011/2012 and 2012/2013 seasons.

\begin{tabular}{|c|c|c|c|c|c|c|c|}
\hline \multirow{2}{*}{ Treatments } & \multicolumn{3}{|c|}{ Number of leaves/tree First season } & \multicolumn{4}{|c|}{ Number of leaves/tree second season } \\
\hline & February & March & April & January & February & March & April \\
\hline $\mathrm{T} 1$ & $22.67^{\mathrm{b}}$ & $13.67^{\mathrm{b}}$ & $4.00^{b}$ & $17.33^{\mathrm{a}}$ & $18.67^{\mathrm{a}}$ & $11.00^{\mathrm{b}}$ & $6.00^{b}$ \\
\hline $\mathrm{T} 2$ & $27.33^{\mathrm{a}}$ & $16.33^{\mathrm{ab}}$ & $2.67^{b}$ & $17.00^{\mathrm{a}}$ & $13.67^{\mathrm{b}}$ & $8.33^{\mathrm{b}}$ & $2.67^{\mathrm{c}}$ \\
\hline $\mathrm{T} 3$ & $23.67^{\mathrm{b}}$ & $14.33^{b}$ & $3.00^{\mathrm{b}}$ & $12.00^{\mathrm{b}}$ & $8.00^{\mathrm{c}}$ & $3.33^{c}$ & $2.00^{\mathrm{c}}$ \\
\hline $\mathrm{T} 4$ & $29.33^{\mathrm{a}}$ & $21.00^{\mathrm{a}}$ & $18.33^{\mathrm{a}}$ & $16.00^{\mathrm{a}}$ & $18.67^{\mathrm{a}}$ & $21.00^{\mathrm{a}}$ & $22.33^{\mathrm{a}}$ \\
\hline $\mathrm{SE} \pm$ & 0.82 & 1.63 & 1.04 & 0.69 & 0.50 & 0.84 & 0.57 \\
\hline
\end{tabular}

Means with the same latter(s) in the same column are not significantly different at 0.05 level of probability according to DNMRT.

$\mathrm{T}_{1}=$ semi-circular; $\mathrm{T}_{2}=$ pits; $\mathrm{T}_{3}=$ deep ditch; $\mathrm{T}_{4}=\mathrm{V}$-shape.

\subsection{Number of Branches/Tree}

In the second season (before mortality of control trees) the V-shaped treatment had significantly higher mean number of branches/tree as compared to both pits and deep ditch treatments for February, March and April, whereas this treatment had no significant differences with the semi-circular for the same period (Table 7).

Table 7. Effect of micro catchment shape on number of branches/tree of Jatropha (before mortality of control trees) during 2011/2012 and 2012/2013 seasons.

\begin{tabular}{|c|c|c|c|c|c|c|c|}
\hline \multirow{2}{*}{ Treatments } & \multicolumn{4}{|c|}{ number of branches/tree First Season } & \multicolumn{3}{|c|}{ number of branches/tree Second Season } \\
\hline & October & November & December & January & October & November & December \\
\hline T0 & $1.00^{\mathrm{a}}$ & $1.00^{\mathrm{a}}$ & $1.00^{\mathrm{a}}$ & $1.00^{\mathrm{a}}$ & $1.00^{\mathrm{a}}$ & $1.00^{\mathrm{a}}$ & $1.00^{\mathrm{a}}$ \\
\hline $\mathrm{T} 1$ & $1.00^{\mathrm{a}}$ & $1.00^{\mathrm{a}}$ & $1.00^{\mathrm{a}}$ & $1.00^{\mathrm{a}}$ & $1.00^{\mathrm{a}}$ & $1.00^{\mathrm{a}}$ & $1.00^{\mathrm{a}}$ \\
\hline $\mathrm{T} 2$ & $1.00^{\mathrm{a}}$ & $1.00^{\mathrm{a}}$ & $1.00^{\mathrm{a}}$ & $1.00^{\mathrm{a}}$ & $1.00^{\mathrm{a}}$ & $1.00^{\mathrm{a}}$ & $1.00^{\mathrm{a}}$ \\
\hline T3 & $1.00^{\mathrm{a}}$ & $1.00^{\mathrm{a}}$ & $1.00^{\mathrm{a}}$ & $1.00^{\mathrm{a}}$ & $1.00^{\mathrm{a}}$ & $1.00^{\mathrm{a}}$ & $1.00^{\mathrm{a}}$ \\
\hline $\mathrm{T} 4$ & $1.00^{\mathrm{a}}$ & $1.00^{\mathrm{a}}$ & $1.00^{\mathrm{a}}$ & $1.00^{\mathrm{a}}$ & $1.00^{\mathrm{a}}$ & $1.00^{\mathrm{a}}$ & $1.00^{\mathrm{a}}$ \\
\hline $\mathrm{SE} \pm$ & 0.00 & 0.00 & 0.00 & 0.00 & 1.00 & 0.96 & 1.41 \\
\hline
\end{tabular}

Means with the same latter(s) in the same column are not significantly different at 0.05 level of probability according to DNMRT.

$\mathrm{T}_{0}=$ control; $\mathrm{T}_{1}=$ semi-circular; $\mathrm{T}_{2}=$ pits; $\mathrm{T}_{3}=$ deep ditch; $\mathrm{T}_{4}=\mathrm{V}$-shape.

On the other hand, in February and April of the second season (after mortality of control trees) the semi-circular treatment significantly increased the number of branches/tree as compared to pits and deep ditch treatments which showed no significant 
differences between them in this period (Table 8).

Table 8. Effect of micro catchment shape on number of branches/tree of Jatropha (after mortality of control trees) during 2011/2012 and 2012/2013 seasons.

\begin{tabular}{llllllll}
\hline \multirow{2}{*}{ Treatments } & \multicolumn{2}{l}{ Number of branches/tree First season } & \multicolumn{4}{l}{ Number of branches/tree Second season } \\
\cline { 2 - 8 } & February & March & April & January & February & March & April \\
\hline T1 & $1.00^{\mathrm{a}}$ & $1.00^{\mathrm{b}}$ & $1.00^{\mathrm{a}}$ & $1.33^{\mathrm{a}}$ & $2.00^{\mathrm{a}}$ & $2.00^{\mathrm{ab}}$ & $2.33^{\mathrm{a}}$ \\
$\mathrm{T} 2$ & $1.00^{\mathrm{a}}$ & $1.00^{\mathrm{b}}$ & $1.00^{\mathrm{a}}$ & $1.00^{\mathrm{a}}$ & $1.00^{\mathrm{b}}$ & $1.33^{\mathrm{bc}}$ & $1.67^{\mathrm{b}}$ \\
$\mathrm{T} 3$ & $1.00^{\mathrm{a}}$ & $1.00^{\mathrm{b}}$ & $1.00^{\mathrm{a}}$ & $1.00^{\mathrm{a}}$ & $1.00^{\mathrm{b}}$ & $1.00^{\mathrm{c}}$ & $1.00^{\mathrm{b}}$ \\
$\mathrm{T} 4$ & $1.00^{\mathrm{a}}$ & $1.67^{\mathrm{a}}$ & $1.00^{\mathrm{a}}$ & $1.67^{\mathrm{a}}$ & $2.00^{\mathrm{a}}$ & $2.67^{\mathrm{a}}$ & $2.67^{\mathrm{a}}$ \\
$\mathrm{SE} \pm$ & 0.00 & 0.16 & 0.00 & 0.22 & $0.02^{2}$ & 0.22 & 0.22 \\
\hline
\end{tabular}

Means with the same latter(s) in the same column are not significantly different at 0.05 level of probability according to DNMRT.

$\mathrm{T}_{1}=$ semi-circular; $\mathrm{T}_{2}=$ pits; $\mathrm{T}_{3}=$ deep ditch; $\mathrm{T}_{4}=\mathrm{V}$-shape.

\section{Discussion}

The study showed that Jatropha under the control treatment survived only 4 months during the first season and 3 months during the second season, after that they were subjected to permanent wilting. Whereas the Jatropha trees under the micro catchment treatments continued to survive. This may be attributed to the exposure of the trees under the control treatment to a condition of water deficit due to low the moisture content, while under the micro- catchments such condition was avoided through availability of water around the root zone as a result of water collection and storage by these techniques. This is in supported of the statement of Dauda and Baiyeri (2009) saying that micro catchment techniques are appropriate for small scale trees planting in any area which has moisture deficit. Al-seekh and Mohammed (2010) mentioned that water harvesting techniques are effective in increasing soil moisture storage, prolonging the growing season and decreasing the amount of supplemental irrigation required for growing fruit trees.

Also Seidahmed et al., (2012) pointed out that the survival of tree species decreased with time as a result of drought due to short rainy season which affect soil water content. After transplantation, rain water harvesting can be used to speed up tree establishment, deep root development and to reduce the mortality rate of trees.

In general plant height and stem thickness of Jatropha trees during the study periods in both seasons was significantly higher under most of the micro catchment techniques as compared to the control, with higher mean of these characters obtained by $\mathrm{V}$-shape, followed by semi-circular and pits treatments. This may be attributed to the availability of water and nutrients around the root zone of these trees in the micro catchments. Xiao et al., (2005) found that for 4 types of micro catchments, plant height and crown diameter of Tamarix ramosissima were significantly higher than the control. The authors attributed this to the effect of these micro catchments on production of more water to be available to the trees. On the other hand, Jianxin et al., (2007) observed that plant height and ear length of Broom - corn millet significantly increased under contour terraces and contour ridge than the control.

The findings of this study also revealed that the monthly increment in plant height under control treatment for the two
Jatropha trees in both seasons was light as compared to the micro catchments, particularly towards January of the first season and December of the second season. Whereas, during October plant height of all treatments including the control was similar, this may infer the importance of availability of water around the root zone and its effect on tree growth.

Number of leaves/tree at most of the study period in both seasons was significantly higher under most of the micro catchment techniques than the control. The significantly higher mean of the number of leaves/tree under the microcatchment treatments may be due to the effect of these techniques on plant height as well as their effect on prevention of leaf shedding as a result of water deficit. The effect of water deficit on leaf shedding was very clear under the control treatment as shown in the number of leaves during January of the first season and December of the second season, when it was obviously reduced as compared to the previous months. This condition did not occur for the micro catchment techniques at this period.

Almost in both seasons for the study period, the number of branches/tree was not significantly different among treatments including the control except between micro catchment techniques towards the end of the season. The number of branches/tree was limited between $1-2$. This could be attributed to the fact that the period of the study was not enough for these trees to show this character particularly for the Jatropha in which the emergency of branches under favorable conditions may take a long time.

\section{Conclusion}

1. The V-shaped water harvesting technique was most effective in enhancing trees growth.

2. There was no significant difference in plant growth parameters (number of branches per plant) in any location due to water harvesting technique.

\section{References}

[1] Aktar, M and Menching, H.G. (1993) Desertification in the Butana Geojournal 31; 41-50.

[2] Alaktar, M.K and Aga.A.A. (1995) Vegetation and Soil conservation, Halab University Faculty of Agricu-lture Der Elzor Ibn Khaldon Printing Press, Damascus. 
[3] Al-Seekh SH. and Mohammad, A.G. (2010). The effect of water harvesting techniques on runoff, sedimentation, and soil properties. College of Agriculture, Hebron University, Hebron, West Bank, Palestine. 14th International Soil Conservation Organization Conference. Water Management and Soil Conservation in Semi-Arid Environments. Marrakech, Morocco, May 14-19, 2010 (ISCO 2010).

[4] Dauda, K.A. and Baiyeri, M.R. (2009). Design and Construction of Negarim Micro Catchment System for Citrus Production. Agricultural Engineering and Water Resources, Institute of Technology, Kwara State Polytechnic, Ilorin, Kwara State, Nigeria.

[5] Jianxin, Z., Dawei Zheng, Yantian Wang, Yu Duan and Yanhua Su. (2007). Two water harvesting type within-field Rainwater harvesting measures and their effects on increasing soil moisture and crop production in north china. College of Resources and Environment, China Agricultural University, Beijing, China, 100094.

[6] Meunive, M. (1996) Forest cover and flood water in small mountain water sheds Unasylva (47)-29.
[7] Omer, A.Mekki and Eltigani, M. Elamin. (1997) Effect of tillage and contour dikking on sorghum establishment and yield on sandy clay soil in Sudan, Soil and tillage research 43229-240.

[8] Salih, A.A and Inanga.S. (1997) in- situ water harvesting and contour dikking for sorghum production and tree establishment in marginal lands (Abstracts of 1997 meeting of Japanese Association for arid land Studies).

[9] Seidahmed H.A, Salih, A.A and Musnad, H.A., (2012). Rehabilitation of Kerrib Lands in Upper Atbara River using Indigenous Trees and Water Harvesting Techniques, Forestry Research Centre -Soba- ARC, Journal of Science and Technology Vol. 13 Agricultural and Veterinary Sciences (JAVS No.1. 104-109).

[10] Xiao, Yan Li, Lian-You Liu, Shang-Yu Gao, Pei-Jun Shi, XueYong Zou, Chun-Lai Zhang, (2005). Microcatchment water harvesting for growing Tamarix ramosissima in the semiarid loess region of China. The Key Lab of Environment Change and Natural Disaster, Ministry of Education, Beijing 100875, China. Forest Ecology and Management 214 (2005) 111-117. 